\title{
The Influence of GCG Implementation on the Performance of BPJS Ketenagakerjaan in Branch Offices in the Region of DKI Jakarta
}

\author{
Andy Faisal Aziz ${ }^{1}$, Edi Prihantoro ${ }^{2}$, I Made Yagustana ${ }^{3}$ \\ ${ }^{1}$ Gunadarma University Postgraduate Masters Program in Management, Jakarta, Indonesia. \\ 2 Lecturer in the Postgraduate Masters Program in Management in Gunadarma University, Jakarta, Indonesia. \\ ${ }^{3}$ Graduated from Gunadarma University Postgraduate Masters Program in 2016, Jakarta, Indonesia.
}

\begin{abstract}
This research was conducted to provide confidence in the effect of the implementation of GCG BPJS Ketenagakerjaan on the performance of branch offices in the DKI Jakarta area. Therefore a theoretical model with 15 hypotheses was proposed to be tested using the SEM method, through 255 respondents who were BPJS Ketenagakerjaan in the DKI Jakarta Region, as the largest contributor area of contributions compared to 10 other regions in Indonesia. Based on this research, it is known that the implementation of GCG in the form of Transparency is very significant, followed by the implementation of the Responsibility principle and the Fairness principle on the Expansion of Participation Performance, Service Satisfaction and Fee Acceptance, and in general there is a positive relationship on the implementation of GCG on Branch Office Performance. Based on this research it is recommended that the BPJS Employment Office be able to optimize the socialization, monitoring and evaluation on an ongoing basis on the implementation of GCG principles for managing the performance of Branch Offices in its area, so that the expected performance can be achieved and the quality and quantity can be continuously improved.
\end{abstract}

Keywords : Transparency, Responsibility, Fairness, Performance, Quality.

\section{INTRODUCTION}

BPJS Ketenagakerjaan's Vision is "To become the National Proud, Secure, Well-Managed and Excellent Social Security Organizing Agency." To achieve this, a planned, systemic and sustainable implementation of Good Corporate Governance (GCG) supported by the completeness of the existing infrastructure and accompanied by commitment of all BPJS Employees is absolutely necessary as a basic capital for the sustainability of the institution's business and able to become a trusted organization by all stakeholders, especially workers.
One of the main benefits of BPJS Employment for workers is to get protection and provide a sense of security to workers, so it is hoped that workers participating in BPJS Employment can focus on working, be more productive and provide quality and effective outputs (results). This will also benefit entrepreneurs and the community, especially in contributing to economic growth for the welfare of society and the progress of the nation and state.

In the last few years BPJS Employment has nationally conducted GCG / GG implementation assessments routinely once a year, in the last 5 (five) years the score of the assessment assessment has increased and always received the title "Very Good". This can be seen in the following details: 


\begin{tabular}{|c|c|c|}
\hline Year & Value & Predicate \\
\hline 2017 & 95,69 & Very Good \\
\hline 2016 & 95,54 & Very Good \\
\hline 2015 & 95,49 & Very Good \\
\hline 2014 & 95,26 & Very Good \\
\hline 2013 & 95,04 & Very Good \\
\hline
\end{tabular}

Source: Governance Implementation Assessment Report BPJS Employment, 2013-2017

This shows that there is an improvement in the implementation of GCG / GG in governance in BPJS Employment, especially in terms of quality. This condition is also supported by the implementation of GCG governance in Regional Offices and Branch Offices, including Regional Offices and Branch Offices in the DKI Jakarta area.

Although testing and empirical research on the relationship between GCG / GG implementation and performance has been widely carried out, and based on these studies there is a positive relationship between GCG / GG implementation and Performance. However, the testing conducted is still general as a large BPJS Employment institution or not many have focused on GCG governance at the BPJS Employment Branch Office as the spearhead of BPJS Ketenagakerjaan's overall performance. The research was conducted among others by I Made Yagustana, Ak., MM. With the title "The Effect of Good Governance Implementation on Employment BPJS Performance" in 2016. Therefore, the author wants to know the level of relationship between the 5 (five) GCG principles consisting of Transparency, Accountability, Responsibility, Independence, and Fairness with the performance variable. namely Expansion of Participation, Participant Satisfaction, and Receipt of Contribution, which is in the Branch Office.
Branch Offices used as the object of research are Branch Offices in the DKI Jakarta area. This is done because the DKI Jakarta area is one of the main barometers of the economy and business center in Indonesia, where many companies, both state and private companies, are based in Jakarta. In addition, Jakarta is usually the center of centralization of the management of the wages of all company employees spread across Indonesia, so that in terms of performance of the BPJS Employment is very significant.

Based on the description above, then on this occasion the researcher will conduct a study entitled "The Effect of Good Corporate Governance Implementation on BPJS Employment Performance at Branch Offices in the DKI Jakarta area". Because BPJS Employment is a public legal entity that organizes a social security system based on nonprofit principles (Law No. 24 of 2011, articles 4 and 7), in this study performance variables are measured based on the Performance of Participation Expansion, Service Satisfaction Performance, and Contribution Acceptance Performance (BPJS Employment Strategic Plan, while Good Governance variables are in accordance with the basic principles of GCG, namely Transparency, Accountability, Responsibility, Independence and Fairness.

\section{METHODS AND MATERIAL}

The term "Corporate Governance" was first introduced by the Cadbury Committee in 1992 in their report which came to be known as the Cadbury Report and was a turning point that was crucial for the practice of Corporate Governance throughout the world. Cadbury Committee (1992) suggests that Corporate Governance is defined as a system that functions to direct and control the company.

Then in 1993, Berle and Means (1993) used the term Good Corporate Governance to classify modern 
corporations as an institution that separates ownership from control, but at that time the phrase Good Corporate Governance was not used relatively until recently. This separation gives authority to managers (managers / directors) to take care of the running of the company, such as managing funds and making company decisions on behalf of the owner. Until the last few years, Good Corporate Governance has developed from time to time, this development emerged as a reaction to various corporate failures as a result of poor corporate governance (Latifa \& Marvyn, 2005).

Corporate Governance can be interpreted literally as "corporate governance". According to Sutedi (2011), Corporate Governance can be defined as a process and structure used by corporate organs (Shareholders / Capital Owners, Commissioners / Supervisory Board, and Directors) to increase business success and corporate accountability in order to realize value or wealth for the holders shares in the long run by taking into account the interests of other stakeholders, based on legislation and ethical values. Furthermore Sutedi (2011) said that Good Corporate Governance is definitively a system that regulates and controls companies to create added value for all stakeholders.

There are two things that are emphasized in this concept, first is the importance of the right of shareholders to obtain information correctly and accurately in a timely manner, and second is the company's obligation to make disclosures (accurate, timely, and transparent to all information on company performance, ownership, and stakeholders. In brief, there are five main components needed in this GCG, namely transparency, accountability, responsibility, independence, and fairness.

\section{Good Governance Principles include:}

1. Transparency, ensuring transparency in decision making and transparency in disclosing information regarding the implementation of social security programs by BPJS Employment in accordance with applicable laws and regulations.

2. Accountability, the implementation of BPJS Ketenagakerjaan business activities that explain the functions, implementation and accountability of each party related to BPJS Ketenagakerjaan Organs in accordance with applicable laws and regulations and generally accepted practices.

3. Responsibility, the implementation of a social security program by BPJS Employment that can explain the role and status of each party involved for each process of making and implementing policies.

4. Independency, professional management of BPJS Labor that is free from conflicts of interest or pressure and or influence from any party that is not in accordance with applicable laws and regulations.

5. Fairness, fairness and equality in fulfilling the rights of each party that arises based on the agreements and legislation in force.

Performance is the result achieved from the behavior of members of the organization (Gibson,1998). So organizational performance is the desired outcome of the organization from behavior the people in it. Kaplan and Norton (1992) developed a benchmark more comprehensive company success (performance), under the name Balanced Scorecard.

Based on the BPJS Employment's strategic objectives, a Key stipulation was prepared Performance Indicators (KPI) of all BPJS Employment Branch Offices that support National BPJS Employment Performance. The main performance of the BPJS Employment Branch Office based on the Strategy Map of the BPJS Employment Strategic Plan each year until 2018 is as follows: 
1. Broadening the scope of membership, as an Extended Performance Performance;

2. Providing services that are easy, friendly, modern, and more useful, as a Service Satisfaction Performance

3. Maintaining the sustainability of DJS and BPJS Employment, increasing the effective and efficient Management Fund, as a Performance of Receiving Dues.

\section{RESEARCH METHODS}

The research model used in this research is multiple regression analysis, which is a regression or prediction model that involves more than one independent variable or predictor or to determine the magnitude of the influence of several independent variables on the dependent variable and between two latent variables. For this reason, the researchers made two model images as shown in Figure 1.

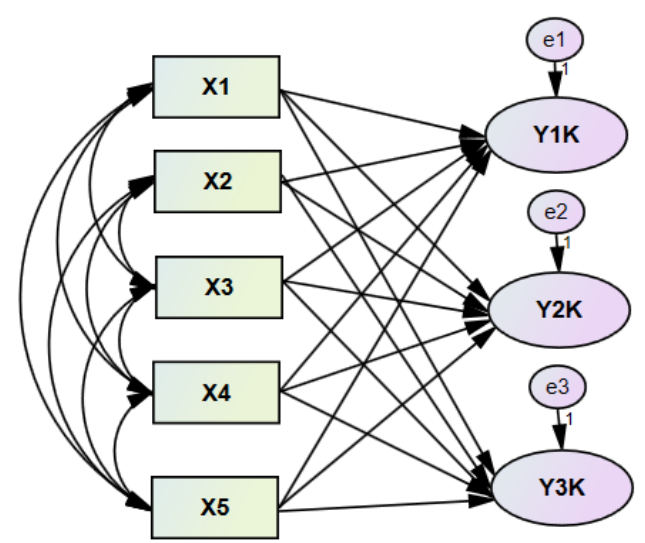

Figure 1:. Design Model for AMOS-SPSS Process

Source: Model processed by researchers, 2019

\section{Information :}

a. GG Principles, namely: X1 = Transparency, X2 = Accountability, $\mathrm{X} 3=$ Responsibility, $\mathrm{X} 4=$ Independence, and X5 = Fairness.

b. Performance Variables in Branch Offices, namely: Y1K = Participation Performance, Y2K = Service Performance, and Y3K = Financial Performance; and

c. $\quad \varepsilon=$ Variables outside the GG that are not examined.

d. The object of this research consists of: Five independent variables (independent) the principles of GG (Transparency, Accountability, Responsibility, Independence, and Fairness) and three dependent variables (dependent) Branch Office performance (Expansion of Membership, Service Satisfaction and Fee Reception).

This research was conducted through a survey approach (Kuncoro, 2013), using a questionnaire as a tool to collect data from all respondents, who are structural and functional employees in all Branch Offices in the DKI Jakarta area. The questionnaire used consisted of a number of questions and / or written statements in the form of operational components of the research variable and several alternative answers had been determined based on a Likert scale. Likert scale according to Sugiyono (2011: 93) is used as a tool to measure the attitudes, opinions and perceptions of a person or group of people about social phenomena. Likert scale has gradations from very positive to very negative.

This questionnaire uses an answer rating system based on the criteria of the answer / statement given by the respondent. The rating scale for these criteria is as follows:
a. Strongly Agree (SS)
, rated 5 (five).
b. Agree (S)
c. Less agree (KS)
, rated 4 ((four).
d. Disagree (TS)
, rated 3 (three)
e. Strongly disagree (STS)
, rated 2 (two).
, rated 1 (one).

Performance is an endogenous variable from this research, namely Expansion of Membership, Service Satisfaction, and Acceptance of Contributions (Financial Effectiveness and Efficiency). Meanwhile 
exogenous variables consist of five principles of GCG, namely Transparency, Accountability, Independence Responsibility and Fairness or abbreviated T.A.R.I.F. The study population was structural and functional employees of the Branch Office in the DKI Jakarta area. Samples were taken using the Non-Random Sampling technique, with Judgment Cooper Cooperative and Emory, 2005). The sample criteria of the respondents are BPJS Ketenagakerjaan employees who actively work at BPJS Ketenagakerjaan both structural and functional and have the official email address of BPJS Ketenagakerjaan. 270 questionnaires were sent via the Google Drive application and distributed directly to all BPJS Employment Branch Offices (17 Kacab) in the DKI Jakarta area. Out of 270 questionnaires sent, only 255 questionnaire answers were filled out completely.

If the sample obtained amounts to 100-150 data for structural models / SEM (Structural Equation Modeling) with up to five latent variables (constructs), and each construct is explained by three or more indicators according to Singgih Santoso (2011) in Siswoyo (2013) ) is considered adequate. Based on calculations using the Slovin method, a reasonable and adequate sample of 701 employees from DKI Jakarta in 2018 with a Error Level of 5\% is 255 employees, with the following calculations:

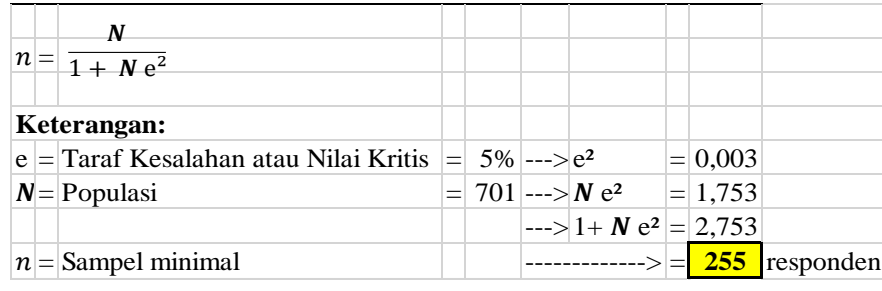

This study uses a structural equation model (Structural Equation Modeling / SEM) with the help of the application of the AMOS (Analysis of Moment Structure) program in conducting data analysis. SEM analysis is a combination of various multivariate techniques that try to analyze the simultaneous relationship between independent and dependent variables (Siswoyo Haryono, et al. 2012).

The SEM (Structural Equation Modeling) method according to Raykov (2000) in Siswoyo Haryono, et all. (2012) is more valid and valid and can be used to provide complete data / information about the relationship between constructs and indicators, as well as relationships between constructs hypothesized (theory) by researchers in a continuous (simultaneous) manner. In addition, SEM will explicitly calculate the measurement error that occurs in the model used.

The thing that needs to be determined in observing the research object (often called the object of observation) is determining the character of the object being observed (observed), this is called a variable. (Sitinjak and Sugiarto (2006) in Siswoyo Haryono, et al. (2012).

The key variable and the concern in SEM is the latent variable according to Siswoyo Haryono, et all. (2012). Unobserved variables in SEM are also called constructs. The latent variable is observed indirectly and imperfectly, and is obtained from the impact or effect of the observed variable. This latent or construct variable is measured by a number of manifest indicators / observed variables and has both exogenous and endogenous characteristics.

Exogenous latent variables are independent variables that affect the dependent variable. In the SEM model, exogenous latent variables are described in the form of arrows that originate from these variables towards endogenous latent variables. And vice versa, endogenous latent variables are dependent variables that are influenced by independent variables, and are illustrated by the arrows that lead to these variables.

In general SEM analysis according to Siswoyo Haryono, et all. (2012) carried out through 2 (two) stages, namely the measurement model stage and the structural model stage, with the following explanation: 
1. Measurement Model Stage, in SEM, each latent construct is usually associated with multiple seasures. The relationship between latent constructs and measurements is carried out through analytic measurement model factors, that is, each latent construct is modeled as a common factor of measurement. "Factor loading" or "factor loads" connecting a construct with its measurements is symbolized by the Greek character "lamda" label $\lambda$. The purpose of the measurement model is to obtain constructs or latent variables that are fit, so that they can be used for subsequent analyzes. Identification of this is done by looking at the degrees of freedom (df) value of the model made. Hypothesis testing can only be done if the SEM model has positive degrees of freedom (df).

2. Structural Model Stage (Structural Model), the structural model is a relationship between latent constructs and this relationship is considered linear, however further development is possible to include non-linear equations. Graphically a line with one arrowhead shows a regression relationship and a line with two arrow heads shows a correlation or covariance. Structural model analysis is intended to first get the most fit or feasible structural model, before testing a hypothesis. Testing the structure of the model can be done by testing the overall model fit which aims to evaluate in general the degree of conformity or Goodness Of Fit between the data and the model (Siswoyo Haryono, et al. 2012). So that a model is said to be fit with overall sample data, if the overall model fit test produces a probability level that is greater than the level of significance $(\alpha)$.

3. Hypothesis Testing, the AMOS Program is used to test hypotheses on the effect of the application of Good Governance on the performance of the BPJS Employment Branch Office in the DKI Jakarta
Region along with the independent variables that serve as proxies for each. Reference in decision making from testing the hypothesis by looking at the probability. namely as follows:

- There is a correlation between exogenous variables.

- There are influences on the variables of Transparency, Accountability, Responsibility, Independence, and Fairness towards Participant Registration, Service Satisfaction, and Receipt of Contributions at the BPJS Employment Branch Office in DKI Jakarta.

Processing with the AMOS program produces data in the form of Regression Weights tables with data / information consisting of: Estimate (b), standard errors (SE), critical ratio (CR). The information shows the level of significance of the influence of an independent variable on the dependent variable. As for the conclusion, a hypothesis is accepted or rejected using information from Probability Level (P) data.

\section{RESULTS AND DISCUSSION}

\section{Results}

Descriptive statistics are performed to determine the observed characteristics of the respondents consisting of 255 respondents who will give an overview of the respondents 'identities formulated in tabular form so that they are easier to understand, as well as regarding respondents' answers. The presentation of descriptive data in this study aims to be able to see the profile of the research data and the relationship between the variables used in the study. The characteristics of the respondents examined by sex, length of service, and position are described in Table 1, as follows:

Table 1. Composition of All Respondents

Based on Gender, Working Period and Position 


\begin{tabular}{|l|l|c|c|}
\hline \multirow{2}{*}{ Uraian } & \multicolumn{1}{|c|}{ Kriteria } & $\begin{array}{c}\text { Frekuensi } \\
\text { (Responden }\end{array}$ & (\%) \\
\hline \multirow{2}{*}{$\begin{array}{l}\text { Jenis } \\
\text { Kelamin }\end{array}$} & Laki-Laki & 127 & 49.80 \\
\cline { 2 - 4 } & Perempuan & 128 & 50,20 \\
\cline { 2 - 4 } Masa & Jumlah & 255 & 100 \\
\hline \multirow{3}{*}{ Kerja } & $<5$ tahun & 113 & 44.30 \\
\cline { 2 - 4 } & 5-15 tahun & 62 & 24,30 \\
\hline \multirow{4}{*}{ Jabatan } & $>15-25$ tahun & 39 & 15,30 \\
\cline { 2 - 4 } & $>25$ tahun & 41 & 16,10 \\
\cline { 2 - 4 } & Jumlah & 255 & 100 \\
\cline { 2 - 4 } & Peiabat & 40 & 15.70 \\
\cline { 2 - 4 } & Fungsional & 215 & 84,30 \\
\hline & Jumlah & 255 & 100 \\
\hline
\end{tabular}

Source: Primary data processed by IBM-SPSS Statistics Viewer, 2019

Testing the model using Structural Equation Modeling (SEM) with the Analysis of Moment Structure (AMOS) program also produces a positive Degress of Freedom (df), which is 715 or above zero so that hypothesis testing can be continued, this can be seen in Table 2 .

Table 2. Comparison of Respondent Data Based on Gender with Tenure and Position

\section{Notes for Model (Default model)}

Computation of degrees of freedom (Default model)

Number of distinct sample moments: $\quad 860$ Number of distinct parameters to be estimated: 145 Degrees of freedom (860 - 145): 715

\section{Result (Default model)}

Minimum was achieved

Chi-square $=2407,965$

Degrees of freedom $=715$

Probability level $=, 000$

Source: Primary data processed with IBM SPSS Amos 2.1.0.0, 2019
In addition, the probability level $=.000$, if the right distribution assumptions are met and if the specified model is correct, then the value is an estimate of the probability to obtain a chi-square statistic equal to the chi-square statistic obtained from the current data set, so that the data departure from the significant model at the 0.05 level. In the table above it can be seen that the model has a good goodness of fit, because the value of the probability level of Chi-Square is greater than 0.05 which is equal to 2407.965. Based on the output produced, it shows that overall the first model is fit with the sample data. In testing the structure of the model will be shown the relationship between constructs that have a causal relationship, (Siswoyo Haryono, et al. 2012). The structure of the model will be described as follows:

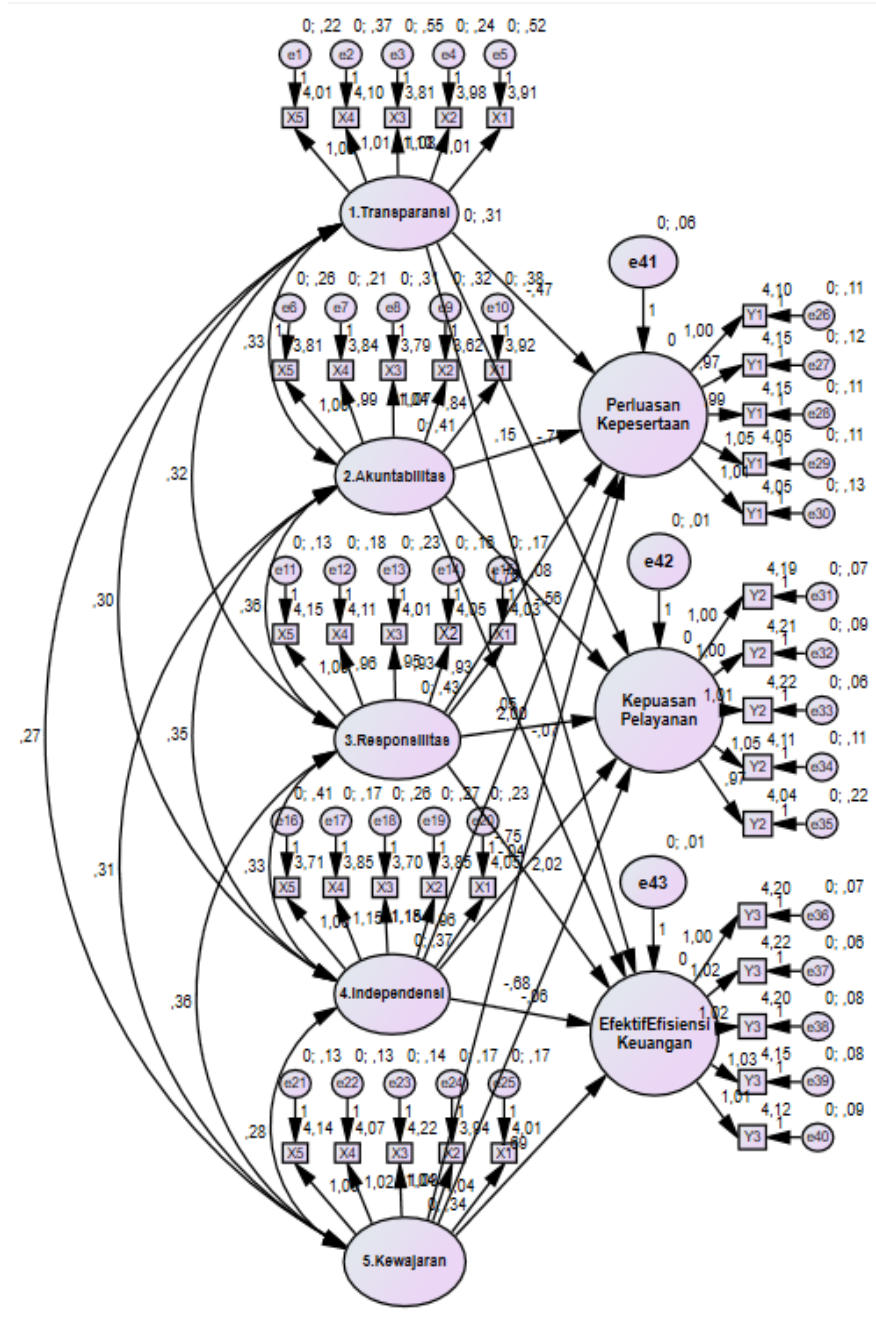


Source: Processed from primary data with IBM SPSS-

AMOS 21.0.0, 2019

Figure 2 : Testing Model Structure

Testing the influence of exogenous variables (independent variables) Good Governance (GG) with the proxy of Transparency (Accountability), Accountability, Responsibility, Independence, and Fairness (Equality and Fairness) on endogenous variables (dependent variable) Performance The BPJS Employment Branch Office with the Proxy of Expansion of Membership, Service Satisfaction, and Receipt of Contributions is indicated by the estimated value (b), standard error (SE), critical ratio (CR), and probability $(\mathrm{P})$ in the Regression Weight table produced by AMOS.

Estimate (b), standard error (SE), critical ratio (CR) indicate the level of significance of the influence of an independent variable on the dependent variable. Meanwhile, the Probability level can be used to draw conclusions from an hypothesis being accepted or rejected.

A high estimated value indicates a large degree of influence. Because the estimated coefficient is not a standardized coefficient, do not look at the size of the estimated value. The estimated value is high but if the standard error is high the same, no significant effect.

The value of the critical ratio (CR) is obtained from the estimated value divided by the standard error (SE). The higher the $C R$ value, the more significant. With a large sample size, a CR value above 1.96 will produce a significant estimation value at the $5 \%$ level, whereas if it is above 2.56 it will be significant at the $1 \%$ level. Standardized estimation values $(\beta)$ can be used to compare whether or not the level of significance of the effect of an independent variable on the dependent variable.
The probability value $(\mathrm{P})$ shown in the Regression Weight table can be used in drawing conclusions. If $\mathrm{P}>$ 0.05 then Ho is accepted, if $\mathrm{P}<0.05$ then Ho is rejected, (Siswoyo Haryono, et al. 2012)

Testing of the Hypothesis of the model ie hypotheses 1 through hypothesis 15 will be based on the following Regression Weight values:

Table 3. Regression Weight

\begin{tabular}{|c|c|c|c|c|c|c|c|}
\hline \multicolumn{3}{|c|}{ Variable } & Estimate & S.E. & C.R. & $\mathbf{P}$ & Label \\
\hline EM & 4 & A & 0,146 & 0,216 & 0,673 & 0,501 & par_33 \\
\hline SS & 4 & A & 0,082 & 0,216 & 0,378 & 0,706 & par_34 \\
\hline SS & 4 & $\mathrm{R}$ & 2,002 & 0,198 & 10,1 & *** & par_35 \\
\hline $\mathrm{EF}$ & 4 & $\mathrm{R}$ & 2,021 & 0,192 & 10,51 & **** & par_36 \\
\hline $\mathrm{EF}$ & 4 & I & $-0,059$ & 0,163 & $-0,361$ & 0,718 & par_37 \\
\hline EM & 4 & $\mathrm{~T}$ & $-0,466$ & 0,241 & $-1,935$ & 0,053 & par_48 \\
\hline SS & 4 & $\mathrm{~T}$ & $-0,736$ & 0,248 & $-2,963$ & 0,003 & par_49 \\
\hline $\mathrm{EF}$ & 4 & $\mathrm{~F}$ & $-0,691$ & 0,181 & $-3,822$ & **** & par_50 \\
\hline EM & 4 & $\mathrm{R}$ & 1,762 & 0,196 & 8,981 & *** & par_51 \\
\hline $\mathrm{EF}$ & 4 & A & $-0,065$ & 0,207 & $-0,314$ & 0,753 & par_52 \\
\hline $\mathrm{EF}$ & 4 & $\mathrm{~T}$ & $-0,557$ & 0,232 & $-2,404$ & 0,016 & par_53 \\
\hline EM & 4 & I & 0,050 & 0,17 & 0,296 & 0,767 & par_54 \\
\hline SS & 4 & I & $-0,044$ & 0,169 & $-0,261$ & 0,794 & par_55 \\
\hline EM & 4 & $\mathrm{~F}$ & $-0,747$ & 0,19 & $-3,942$ & *** & par_56 \\
\hline SS & 4 & $\mathrm{~F}$ & $-0,677$ & 0,187 & $-3,624$ & *** & par_57 \\
\hline X15 & 4 & $\mathrm{~T}$ & 1 & & & & \\
\hline X14 & 4 & $\mathrm{~T}$ & 1,012 & 0,092 & 11,02 & *** & par_1 \\
\hline X13 & 4 & $\mathrm{~T}$ & 1,103 & 0,107 & 10,28 & **** & par_2 \\
\hline X12 & 4 & $\mathrm{~T}$ & 1,076 & 0,085 & 12,73 & *** & par_3 \\
\hline $\mathrm{X} 11$ & 4 & $\mathrm{~T}$ & 1,01 & 0,102 & 9,884 & **** & par_4 \\
\hline X25 & 4 & A & 1 & & & & \\
\hline X24 & 4 & A & 0,994 & 0,07 & 14,18 & *** & par_5 \\
\hline $\mathrm{X} 23$ & 4 & A & 1,041 & 0,079 & 13,18 & $* * *$ & par_6 \\
\hline $\mathrm{X} 22$ & 4 & A & 1,066 & 0,081 & 13,23 & **** & par_7 \\
\hline X21 & 4 & A & 0,837 & 0,077 & 10,89 & *** & par_8 \\
\hline X35 & 4 & $\mathrm{R}$ & 1 & & & & \\
\hline
\end{tabular}




\begin{tabular}{|c|c|c|c|c|c|c|c|}
\hline \multicolumn{3}{|c|}{ Variable } & \multirow{2}{*}{$\begin{array}{c}\text { Estimate } \\
0,958\end{array}$} & \multirow{2}{*}{$\begin{array}{c}\text { S.E. } \\
0,053\end{array}$} & \multirow{2}{*}{$\begin{array}{c}\text { C.R. } \\
18,06\end{array}$} & \multirow{2}{*}{$\frac{\mathrm{P}}{* * *}$} & \multirow{2}{*}{\begin{tabular}{|l|} 
Label \\
par_9
\end{tabular}} \\
\hline X34 & 4 & $\mathrm{R}$ & & & & & \\
\hline X33 & 4 & $\mathrm{R}$ & 0,949 & 0,057 & 16,7 & $* * *$ & par_10 \\
\hline X32 & 4 & $\mathrm{R}$ & 0,933 & 0,051 & 18,46 & $* * *$ & par_11 \\
\hline X31 & 4 & $\mathrm{R}$ & 0,927 & 0,051 & 18,04 & $* * *$ & par_12 \\
\hline $\mathrm{X} 45$ & 4 & I & 1 & & & & \\
\hline $\bar{X} 44$ & 4 & I & 1,15 & 0,092 & 12,48 & $* * *$ & par_13 \\
\hline $\mathrm{X} 43$ & 4 & I & 1,18 & 0,099 & 11,9 & **** & par_14 \\
\hline $\mathrm{X} 42$ & 4 & I & 1,148 & 0,098 & 11,73 & $* * *$ & par_15 \\
\hline $\mathrm{X} 41$ & 4 & I & 0,964 & 0,085 & 11,34 & $* * *$ & par_16 \\
\hline $\mathrm{X} 55$ & 4 & $\mathrm{~F}$ & 1 & & & & \\
\hline $\mathrm{X} 54$ & 4 & $\mathrm{~F}$ & 1,023 & 0,057 & 17,96 & *** & par_17 \\
\hline $\mathrm{X} 53$ & 4 & $\mathrm{~F}$ & 1,041 & 0,059 & 17,58 & *** & par_18 \\
\hline $\mathrm{X} 52$ & 4 & $\mathrm{~F}$ & 1,031 & 0,061 & 16,85 & $* * *$ & par_19 \\
\hline $\mathrm{X} 51$ & 4 & $\mathrm{~F}$ & 1,044 & 0,062 & 16,79 & *** & par_20 \\
\hline Y11 & 4 & EM & 1 & & & & \\
\hline Y21 & 4 & EM & 0,966 & 0,044 & 21,75 & $* * *$ & par_21 \\
\hline Y31 & 4 & EM & 0,989 & 0,043 & 22,81 & $* * *$ & par_22 \\
\hline Y41 & 4 & EM & 1,05 & 0,045 & 23,19 & *** & par_23 \\
\hline Y51 & 4 & EM & 1,011 & 0,046 & 21,94 & *** & par_24 \\
\hline Y12 & 4 & SS & 1 & & & & \\
\hline Y22 & 4 & SS & 0,996 & 0,039 & 25,29 & *** & par_25 \\
\hline Y32 & 4 & SS & 1,01 & 0,036 & 27,79 & *** & par_26 \\
\hline$\overline{Y 42}$ & 4 & SS & 1,05 & 0,043 & 24,53 & $* * *$ & par_27 \\
\hline Y52 & 4 & SS & 0,968 & 0,053 & 18,23 & *** & par_28 \\
\hline Y13 & 4 & $\mathrm{EF}$ & 1 & & & & \\
\hline Y23 & 4 & $\mathrm{EF}$ & 1,016 & 0,036 & 28,06 & *** & par_29 \\
\hline Y33 & 4 & $\mathrm{EF}$ & 1,016 & 0,038 & 26,7 & *** & par_30 \\
\hline Y43 & 4 & $\mathrm{EF}$ & 1,028 & 0,039 & 26,45 & *** & par_31 \\
\hline Y53 & 4 & $\mathrm{EF}$ & 1,007 & 0,039 & 25,54 & *** & par_32 \\
\hline
\end{tabular}

X5* Fairness

$\mathrm{F}$

Source: Processed from primary data with IBM SPSS-AMOS 21.0.0, 2019

Based on the output produced, it is known that there are two nature of the effects produced by 5 (five) Independent variables (Transparency, Accountability, Responsibility, Independence, and Fairness). of 3 (three) Dependent variables (Expansion of Membership, Service Satisfaction, and Receipt of Contributions (Effective_Finance Eficiency). For the basis of analyzing the outputs, refer to Chapter III of the Research Method described earlier.

In testing the regression coefficient on the positive or negative influence of the hypothesis of the independent variables on each performance variable, it is necessary to test the results of Standardized Regression Weights Performance as presented in Table 4.

Table 4. Standardized Regression Weight Performance

\begin{tabular}{|c|c|c|}
\hline \multicolumn{2}{|c|}{$\begin{array}{c}\text { Standardized Regression Weights: (Group } \\
\text { number } 1 \text { - Default model) }\end{array}$} & Estimate \\
\hline $\begin{array}{l}\text { Expansion of } \\
\text { Membership }\end{array}$ & Transparency & $-0,38$ \\
\hline $\begin{array}{l}\text { Effective_Finance } \\
\text { Eficiency }\end{array}$ & Transparency & $-0,48$ \\
\hline Service Satisfaction & 4 Transparency & $-0,637$ \\
\hline $\begin{array}{l}\text { Expansion of } \\
\text { Membership }\end{array}$ & 4 Accountability & 0,136 \\
\hline Service Satisfaction & 4 Accountability & 0,081 \\
\hline $\begin{array}{l}\text { Effective_Finance } \\
\text { Eficiency }\end{array}$ & Accountability & $-0,064$ \\
\hline $\begin{array}{l}\text { Effective_Finance } \\
\text { Eficiency }\end{array}$ & Responsibility & 2,034 \\
\hline Service Satisfaction & 4 Responsibility & 2,026 \\
\hline $\begin{array}{l}\text { Expansion of } \\
\text { Membership }\end{array}$ & Responsibility & 1,681 \\
\hline $\begin{array}{l}\text { Expansion of } \\
\text { Membership }\end{array}$ & Independency & 0,045 \\
\hline
\end{tabular}




\begin{tabular}{|l|c|}
\hline $\begin{array}{c}\text { Standardized Regression Weights: (Group } \\
\text { number 1 - Default model) }\end{array}$ & Estimate \\
\hline Service Satisfaction 4 Independency & $-0,041$ \\
\hline $\begin{array}{l}\text { Effective_Finance } \\
\text { Eficiency }\end{array}$ Independency & $-0,055$ \\
\hline Service Satisfaction $\quad$ Fairness & $-0,611$ \\
\hline $\begin{array}{l}\text { Effective_Finance } \\
\text { Eficiency }\end{array}$ Fairness & $-0,621$ \\
\hline $\begin{array}{l}\text { Expansion of } \\
\text { Membership }\end{array}$ & $-0,637$ \\
\hline
\end{tabular}

Source: Processed from primary data with IBM SPSSAMOS 21.0.0, 2019.

\section{Discussion}

Details and descriptions of the results of testing hypotheses 1 through 15 are as follows:

a. Hypothesis 1: Influence of Transparency on Participation Expansion Performance. Based on Table 3 the results of testing the first hypothesis are rejected ( $\mathrm{P}$ value $0.053>0.050$ ) which means that the application of GG principles, namely Transparency, does not affect the performance of Participation Expansion in the BPJS Employment branch office in the DKI Jakarta area. This happens because there must still be restrictions in applying the principle of Transparency, especially which can have an impact on the reluctance of workers to register or be registered as BPJS Employment participants. The limits in question include: very sensitive audit results, internal negative issues of the BPJS Employment, and matters that politically affect the policies taken by BPJS Ketenagakerjaan management (ASN failed to become BPJS Employment participants, nonfunctioning BPJS Laws, etc. ) which can damage the image and disrupt BPJS Employment Operations in the public eye.

b. Hypothesis 2: The Effect of Transparency on Service Satisfaction Performance. Based on Table 3 , the results of testing on the second hypothesis are accepted ( $\mathrm{P}$ value $0.003<0.050$ ), which means that the application of the GG principle variable, Transparency has a significant effect on the performance of Service Satisfaction at the BPJS Employment branch office in the DKI Jakarta area. This can be seen from the indication of the ease of gaining access to procedures and procedures for services from personnel to participants, the emphasis on information about the absence of illegal or free fees in providing services to participants, and clear strategies or policies conveyed to the Branch Office.

c. Hypothesis 3: Influence of Transparency on Contribution Receipt Performance (Financial Efficiency and Effectiveness). Based on Table 3, the results of testing on the third hypothesis are accepted, which means that the application of GG principles, namely Transparency, affects the performance of Contribution Receipts (Financial Effectiveness and Efficiency) at the BPJS Employment branch office in the DKI Jakarta area, including information being presented and sent. on line and up to date for each participant, including contributions, development results, and the final balance of JHT participants, and the programs that are followed.

d. Hypothesis 4: Effect of Accountability on the Performance of Participation Expansion. Based on Table 3, the results of testing the fourth hypothesis are rejected, which means that the application of GG principles, namely Accountability, does not affect the performance of the Expansion of Membership in the BPJS Employment branch office in the DKI Jakarta area. This has the tendency to be internal obligations of the Central Management and Regional / Branch Offices in making accountability of operations carried out to the Head Office. This has no effect between accountability and expanding membership.

e. Hypothesis 5 Effect of Accountability on Service Satisfaction Performance. Based on Table 3, the 
results of testing the fifth hypothesis are rejected, which means that the application of the GG principle, namely Accountability, does not affect the performance of Service Satisfaction at the BPJS Employment branch office in the DKI Jakarta area. This is related to the absence of influence on the accountability of the implementation of activities budgeted in the annual work plan, because this is a form of accountability from the Employment BPJS to Management, the Supervisory Board and the Government (as the Owner / Owner).

f. Hypothesis 6 Effect of Accountability on Performance in Receiving Dues (Financial Effectiveness and Efficiency). Based on Table 3, the results of testing the sixth hypothesis are rejected, which means that the application of GG principles, namely Accountability, does not affect the performance of Contribution Receipts (Financial Effectiveness and Efficiency) at the BPJS Employment branch office in the DKI Jakarta area. This more leads to the realization of the RKAT's accountability to support the operational BPJS Ketenagakerjaan Office does not affect the receipt of contributions (effective and financial efficiency).

g. Hypothesis 7 Effect of Responsibility on the Performance of Participation Expansion. Based on Table 3, the results of testing the seventh hypothesis are accepted, which means that the application of GG principles, namely Responsibility, has a significant effect on the performance of Participation Expansion at the BPJS Employment branch office in the DKI Jakarta area. This can be seen from the good running of the Corporate Social Responsibility (CSR) program to the public, so that people are more familiar with BPJS Employment.

h. Hypothesis 8 Effect of Responsibility on Service Satisfaction Performance. Based on Table 3, the results of testing the eighth hypothesis are accepted, which means that the application of GG principles, namely Responsibility, significantly influences the performance of BPJS Employment Service Satisfaction in the DKI Jakarta area. Service satisfaction is an obligation of BPJS Employment so that employees at the branch office can provide the best service. One of them is the attention of complaints, especially the complaints of participants who are always followed up properly will affect the satisfaction of participants' services.

i. Hypothesis 9 Effect of Responsibility on the Performance of Fee Receipts (Financial Effectiveness and Efficiency). Based on Table 3, the results of testing the ninth hypothesis are accepted, which means that the application of the GG principle variable, namely Responsibility, has a significant effect on the performance of the BPJS Employment Branches Contribution Reception in the DKI Jakarta area. This can also be seen one of them is the good running of the Corporate Social Responsibility (CSR) program to the public, which gives awareness to BPJS Employees participants that from the management of funds or contributions made by BPJS Employment that come from payment of BPJS Employment contributions from participants also used for social activities that help the general public. This gives participants awareness and confidence to pay dues at the right time and amount, so that it affects the increase in revenue collection or increases in effective and efficient financial management.

j. Hypothesis 10: The Effect of Independence on Independence of Participation Expansion Performance. Based on Table 3, the results of testing the tenth hypothesis are rejected, which means that the application of GG principles, namely Independence, does not affect the performance of the BPJS Employment Expansion in the DKI Jakarta area. This tends to be seen more from the independence in carrying out branch 
office operations, this is not a concern of the community in order to become a participant in the BPJS Employment.

k. Hypothesis 11 Effect of Independence (Independence) on Service Satisfaction Performance. Based on Table 3, the eleventh hypothesis testing results are rejected, which means that the application of the GG principle variable, namely Independence, does not affect the performance of BPJS Employment Service Satisfaction in the DKI Jakarta area. Independence in this matter in carrying out branch office operations, this matter is not the concern of employees or the public in assessing the performance of BPJS Employment Service satisfaction.

1. Hypothesis 12 Effect of Independence (Independence) on the Performance of Receiving Dues (Financial Effectiveness and Efficiency). Based on Table 3, the results of testing on the twelfth hypothesis are rejected, which means that the application of the GG principle, namely Independence, does not affect the performance of the Duties (Financial Effectiveness and Efficiency) of the BPJS Employment branch in the DKI Jakarta area. Independence in this matter in carrying out branch office operations, this is due to the certainty in payment of contributions, both value and timeliness that is automatically systemized, so this does not affect the performance of Receiving Dues (Financial Effectiveness and Efficiency) of BPJS Employment Office.

m. Hypothesis 13 Effect of Fairness on Participation Expansion Performance. Based on Table 3, the results of the testing of the thirteenth hypothesis are accepted, which means that the application of GG principles, Fairness, has a significant effect on the performance of BPJS Employment Expansion in the DKI Jakarta area. Fairness in policies (Law, Presidential Regulation, Perdir, SOP) to attract participants to become BPJS Employment participants affects the performance of BPJS Employment Expansion Participation.

n. Hypothesis 14 Effect of Fairness on Service Satisfaction Performance. Based on Table 3, the test results of the fourteenth hypothesis are accepted, which means that the application of the GG principle, Fairness, has a significant effect on the performance of BPJS Employment Service Satisfaction in the DKI Jakarta area. Fairness in policies (Law, Presidential Regulation, Perdir, SOP) to provide services to BPJS Employee participants affects the performance assessment of BPJS Employment Service Satisfaction.

o. Hypothesis 15 Effect of Fairness on Performance in Receiving Dues (Financial Effectiveness and Efficiency). Based on Table 3, the results of the testing of the fifteenth hypothesis are accepted, which means that the application of the GG principle, Fairness, has a significant effect on the performance of Contribution Receipts (Financial Effectiveness and Efficiency) at the BPJS Employment branch office in the DKI Jakarta area. Fairness in policies (Law, Presidential Regulation, Perdir, SOP) for determining fees (considering Provincial Minimum Wages / City or Regency Minimum Wages) and the ease in making payment of contributions, as well as their use for the convenience of participants in paying BPJS Employment program contributions affect the performance of Contribution Revenues (Effectiveness and Financial Efficiency) BPJS Employment Office.

Then in Table 6 below it is seen that all estimates are positive with the understanding that if the parameters of each variable increase by 1 point, then the value of the variable variables will also increase according to their respective estimates contained in the Table. 
Table 6. Standardized Regression Weight Parameters for Each Independent Variable

\begin{tabular}{|c|c|c|c|c|c|c|c|}
\hline \multicolumn{3}{|c|}{$\begin{array}{c}\text { Standardized } \\
\text { Regression } \\
\text { Weights: (Group } \\
\text { number } 1 \text { - } \\
\text { Default model) }\end{array}$} & \multirow{2}{*}{$\begin{array}{l}\text { Est. } \\
0,77\end{array}$} & \multicolumn{3}{|c|}{$\begin{array}{c}\text { Standardized } \\
\text { Regression } \\
\text { Weights: (Group } \\
\text { number } 1 \text { - } \\
\text { Default model) }\end{array}$} & \multirow{2}{*}{$\begin{array}{l}\text { Est. } \\
0,86\end{array}$} \\
\hline $\mathrm{X} 12$ & 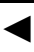 & $\mathrm{T}$ & & X54 & 4 & $\mathrm{~F}$ & \\
\hline X15 & 1 & $\mathrm{~T}$ & 0,76 & X55 & 4 & $\mathrm{~F}$ & 0,86 \\
\hline $\mathrm{X} 14$ & 1 & $\mathrm{~T}$ & 0,68 & X53 & 4 & $\mathrm{~F}$ & 0,85 \\
\hline X13 & 4 & $\mathrm{~T}$ & 0,64 & X52 & 4 & $\mathrm{~F}$ & 0,83 \\
\hline $\mathrm{X} 11$ & 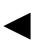 & $\mathrm{T}$ & 0,62 & X51 & 4 & $\mathrm{~F}$ & 0,83 \\
\hline X24 & 1 & & 0,81 & Y41 & 4 & EM & 0,91 \\
\hline X25 & 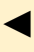 & A & 0,79 & Y11 & 4 & EM & 0,90 \\
\hline X22 & 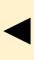 & A & 0,77 & Y31 & 4 & EM & 0,90 \\
\hline X23 & 4 & A & 0,77 & Y51 & 4 & EM & 0,89 \\
\hline $\mathrm{X} 21$ & 1 & A & 0,66 & Y21 & 4 & EM & 0,88 \\
\hline X35 & 1 & $\mathrm{R}$ & 0,88 & Y32 & 4 & SS & 0,94 \\
\hline X32 & 1 & $\mathrm{R}$ & 0,84 & Y12 & & SS & 0,92 \\
\hline X34 & & $\mathrm{R}$ & 0,83 & Y22 & 4 & SS & 0,91 \\
\hline X31 & & $\mathrm{R}$ & 0,83 & Y42 & 4 & SS & 0,90 \\
\hline X33 & 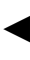 & $\mathrm{R}$ & 0,79 & Y52 & 4 & SS & 0,80 \\
\hline X44 & 4 & I & 0,86 & Y23 & 4 & $\mathrm{EF}$ & 0,93 \\
\hline $\mathrm{X} 43$ & 4 & I & 0,82 & Y13 & 4 & $\mathrm{EF}$ & 0,93 \\
\hline $\mathrm{X} 42$ & 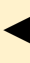 & I & 0,80 & Y33 & 4 & $\mathrm{EF}$ & 0,92 \\
\hline $\mathrm{X} 41$ & 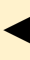 & I & 0,77 & Y43 & 4 & $\mathrm{EF}$ & 0,92 \\
\hline X45 & 4 & I & 0,69 & Y53 & 4 & $\mathrm{EF}$ & 0,91 \\
\hline
\end{tabular}

Source: Processed from primary data with IBM SPSS-AMOS 21.0.0, 2019

To better know the effect of each variable, we will use the test results in Table 3 Regression Weight as a basis for measuring the level of influence, so we can describe the effect of each Independent GCG variable on Branch Offices in the DKI Jakarta area, as follows:

1. Discussion of the effect of Transparency on 4 (four) other independent variables

Based on the results of the tests and analyzes that have been carried out above, it is known that the GCG
Transparency variable has a significant effect on the performance variable. Insignificant service (Hypothesis Rejected). Transparency is guaranteed transparency in decision making and openness in disclosing information regarding the implementation of social security programs by the BPJS Employment Branch Office in the DKI Jakarta area in accordance with applicable laws and regulations. This shows that the efforts of the BPJS Employment Branch Office in the DKI Jakarta area in applying the principle of Transparency to support the operations and performance of Branch Offices have not all had a direct and significant impact on Branch Office Performance. Then from the five parameters of the variables measured in Table 6. Regression Weight is known that all have an influence on transparency (openness) as seen from Probability $(\mathrm{P})$ with a default value of 0.001 $\left.{ }^{* * *}\right)$ or $<0.05$. This shows that the efforts of the BPJS Ketenagakerjaan Branch Office Management in the DKI Jakarta area to apply the principle of Transparency to support the operational and performance of the Branch Office have seen a significant effect on the Performance of the Branch Office through the values of the five parameters mentioned above and the probability $(\mathrm{P})$ of the five paremeters $<0.5$.

2. Discussion on the effect of Accountability on 4 (four) other independent variables

Based on some of the results of tests and analyzes that have been done above, it is known that the GCG Accountability variable significantly influences the performance variable Expansion of Participation or Hypothesis or H4 Received, while the effect on the performance of Contribution Reception (Financial Effectiveness and Efficiency) and Service Satisfaction performance Insignificant or Rejected Hypothesis. Accountability is the implementation of BPJS Ketenagakerjaan business activities that explain the functions, implementation and accountability of each party related to BPJS Ketenagakerjaan Organs in accordance with applicable laws and regulations and generally accepted practices. This also shows that the 
efforts of BPJS Ketenagakerjaan Management in the DKI Jakarta area in applying the Accountability principle to support the operations and performance of Branch Offices have not all had a direct and significant impact on Branch Office Performance. Then from the variables measured in Table 6. Regression Weight there are five parameters of the accountability variable that are known to know that all of them have an influence on the accountability variable as seen from Probability $(\mathrm{P})$ with a default value of $0.001\left(^{* * *}\right)$ or $<0.05$. This shows that the efforts of BPJS Ketenagakerjaan Branch Office Management in the DKI Jakarta area in applying the Accountability principle to support the operations and performance of Branch Offices have seen a significant effect on Branch Office Performance, through the values of the five parameters mentioned above and the probability $(\mathrm{P})$ of the five paremeters $<0.05$.

3. Discussion on the effect of Responsibility on 4 (four) other independent variables

Based on the results of tests and analyzes that have been carried out above, it is known that the GCG Responsibility variable has a significant effect on all or all three hypotheses or H1 Accepted, consisting of: H7: Application of the Responsibility Principle has a significant effect on the Expansion of Participation; H8 Application of the Responsibility Principle has a significant effect on Service Satisfaction; H9: Application of the Responsibility Principle has a significant effect on the Acceptance of Contributions. Responsibility is the implementation of a social security program by the BPJS Employment Branch Office that can explain the role and status of each party related to BPJS Employment for each process of making and implementing policies in BPJS Employment especially those related to the BPJS Employment Branch Office in the DKI Jakarta area . The foregoing shows that BPJS Ketenagakerjaan Management efforts in the DKI Jakarta area in applying the Responsibility principle to support the operations and performance of Branch Offices have a direct and significant impact on Branch Office Performance. Then from the variables measured in Table 6. Regression Weight there are five parameters of the Responsibility variable measured known that all have an influence on the Responsibility variable as seen from Probability $(\mathrm{P})$ with a default value of 0.001 $\left.{ }^{* * *}\right)$ or $<0.05$. This shows that the efforts of the BPJS Ketenagakerjaan Branch Office Management in the DKI Jakarta area to apply the Responsibility principle to support the operational and performance of Branch Offices have seen significant effects on Branch Office Performance, through the values of the five parameters mentioned above and the probability $(\mathrm{P})$ the five parameters are $<0.05$.

4. Discussion of the effect of Independence on 4 (four) other independent variables

Based on some of the results of tests and analyzes that have been carried out above, it is known that the GCG Independency variable has a significant effect on the performance variable Service Satisfaction or Hypothesis or H4 Received, while the effect on the performance of Contribution Reception (Financial Effectiveness and Efficiency) and Expansion of Participation performance Insignificant or Hypothesis Rejected (Ho Rejected). Independence is the implementation of business activities in BPJS Employment Branch Offices throughout the DKI Jakarta area, which explains the function, implementation and accountability of each party related to BPJS Ketenagakerjaan Organs in accordance with applicable laws and regulations and generally accepted practices. This also shows that the efforts of BPJS Ketenagakerjaan Management in the DKI Jakarta area in applying the principle of Independence to support the operational and performance of Branch Offices have not all had a direct and significant impact on Branch Office Performance. Then from the variables measured in Table 6. Regression Weight there are five parameters of the Independent variable measured. It is known that all of them have an influence on the Independence variable as seen from 
Probability (P) with a default value of $0.001\left(^{* * *}\right)$ or < 0.05. This shows that the efforts of the BPJS Ketenagakerjaan Branch Office Management in the DKI Jakarta area in applying the principle of Independence to support the operational and performance of the Branch Office have seen significant effects on the Performance of Branch Offices, through the values of the five parameters mentioned above and the probability $(\mathrm{P})$ the five parameters are $<0.05$.

5. Discussion of the effect of Fairness on 4 (four) other independent variables

Based on the results of tests and analyzes that have been carried out above, it is known that GCG variables significantly influence two of the three hypotheses or H1 Accepted, which consist of: H14: Application of the Fairness Principle has a significant effect on Service Satisfaction; H15: The application of the Fairness Principle has a significant effect on the Acceptance of Contributions; Fairness is fairness and equality in fulfilling the rights of each party that arises based on agreements and legislation in force, especially those related to BPJS Employment Branch Offices in the DKI Jakarta area. The foregoing shows that BPJS Ketenagakerjaan Management efforts in the DKI Jakarta area in applying the Fairness principle to support the operations and performance of Branch Offices have had quite a direct and significant impact on Branch Office Performance. Then from the variables measured in Table 6. Regression Weight there are five parameters of the Fairness variable measured, known that all have an influence on the Fairness variable as seen from Probability $(\mathrm{P})$ with a default value of $\left.0.001{ }^{(* *}\right)$ or $<0.05$. This shows that the efforts of BPJS Ketenagakerjaan Branch Office Management in the DKI Jakarta area in applying the Fairness principle to support the operational and performance of Branch Offices have seen a significant effect on Branch Office Performance, through the values of the five parameters mentioned above and the probability $(\mathrm{P})$ the five parameters $<0.05$.

\section{IV.CONCLUSION}

1. Of the 5 (five) principles of Good Corporate Governance (GCG), there are 2 (two) principles of GCG (Responsibility) and Fairness have a significant influence on the 3 (three) indicators of BPJS Employment Branch Office Performance, in order its significance is as follows:

$>$ The application of the Responsibility Principle has a positive and significant effect on the three performance indicators (Increasing Membership, Service Satisfaction and Receiving Contributions / Financial Effectiveness and Efficiency). In addition, Responsibility has the highest influence compared to other GCG principles. This shows that the three main performances at the Branch Offices in the DKI Jakarta area are strongly influenced by the suitability of the management of the BPJS Ketenagakerjaan for the applicable laws and regulations.

The application of the Fairness Principle has a negative and significant effect on the three performance indicators (Increased Participation, Participant Satisfaction and Fee Acceptance). This shows that the three main performances at the Branch Office are strongly influenced by fairness and equality in fulfilling the rights of stakeholders.

$>$ While the Principle of Independence (Independence), Transparency (Accountability) and Accountability (Accountability) do not have a significant effect on the three performance indicators (Increased Membership, Service Satisfaction and Reception of Contributions / Effectiveness and Financial Efficiency).

2. There is a relationship between the Five GCG Principles (Transparency, Accountability, Responsibility, Independence and Fairness), with the highest average relationship being the Responsibility principle, especially in relation to the principle of Accountability and Fairness. 
3. Performance Achievement of BPJS Employment Branch Offices in the DKI Jakarta area is strongly influenced by the principle of Responsibility in implementing the principles of Good Corporate Governance (GCG), compared to the application of other GCG principles. This shows that the application of Good Governance which is a combination of the five principles has a significantly different effect on the achievement of Branch Office performance in the DKI Jakarta area.

\section{REFERENCES}

[1]. Organization for Economic Cooperation and Development (OECD). 2015.G20/OECD Principles of Corporate Governance. Paris : OECD Publishing.

[2]. Sugiyono. 2011. Metode Penelitian Kuantitatif, Kualitatif dan R\&D. Alfabeta : Bandung.

[3]. Sugiyono. 2017. Metode Penelitian Kuantitatif, Kualitatif, dan R\&D. Bandung: Alfabeta.

[4]. Sutedi, Adrian. 2011. Good Corporate Governance. Jakarta : Sinar Grafika.

[5]. Yagustana, I Made Gede. 2016. Pengaruh Implementasi Good Governance Terhadap Kinerja BPJS Ketenagakerjaan. Tesis. Jakarta : Program Pascasarjana, Universitas Gunadarma.

Journals and Papers

[6]. Mohd Che Haat, H. R. Raaman, Sakthi Mahenthiran. 2008. Corporate Governance, Transparency and Performance of Malaysian Companies. Management Auditing Journal, Butler University.

[7]. Yagustana, I Made Gede. 2016. Pengaruh Implementasi Good Governance Terhadap Kinerja BPJS Ketenagakerjaan. Jurnal. Jakarta : Program Pascasarjana, Universitas Gunadarma.
[8]. Jöreskog, K. \& Sörbom, D. 1993. LISREL 8: structural equation modelling with the SIMPLIS command language. Chicago, IL: Scientific Software International Inc.

Internet Site Links

[9]. Confirmatory Factor Analysis (Analisis Faktor Konfirmatori): dengan Lisrel dan AMOS by Hendry.(https://teorionline.wordpress.com/201 1/12/20/confirmatory-factor-analysisIntroduction). 2011.

[10]. Corporate Governance di Indonesia Terburuk di Asia, Inay/Apr, 26 Juli 2000. (https://www.hukumonline.com/berita/baca/hol 189/corporate-governance-di-indonesiaterburuk-di-asia), 2000.

[11]. McKinsey \& Company, Global Investor Opinion Survey 2002 : Key Findings. July. (http://www.eiod.org/uploads/Publications/Pdf/ II-Rp-4-1.pdf), 2002.

[12]. Organization for Economic Cooperation and Development (OECD). Principles of Corporate Governance, OECD Publishing (https://doi.org/10.1787/9789264236882-en).

[13]. Wikipedia, Cadbury Report (https://en.wikipedia.org/wiki/Cadbury_Report)

[14]. Sejarah singkat BPJS Ketenagakerjaan (https://www.bpjsketenagakerjaan.go.id/sejarah. html)

[15]. Sevilla, Consuelo G. et. al. Research Methods. Rex Printing Company. Quezon City. (http://analisisstatistika.blogspot.com/2012/09/m enentukan-jumlah-sampel-dengan rumus.html, 2007.

[16]. Vo, Duc, and Thuy Phan. Corporate Governance and Firm Performance : Empirical Evidence from Vietnam. September 2013. (https://www.researchgate.net/publication/3012 24738_Corporate_Governance_and_Firm's_Perf ormance_Empirical_Evidence_from_Vietnam 


\section{Cite this article as :}

Andy Faisal Aziz, Edi Prihantoro, I Made Yagustana, "The Influence of GCG Implementation on the Performance of BPJS Ketenagakerjaan in Branch Offices in the Region of DKI Jakarta", International Journal of Scientific Research in Science and Technology (IJSRST), Online ISSN : 2395-602X, Print ISSN : 2395-6011, Volume 6 Issue 6, pp. 37-53, November-December 2019. Available at doi : https://doi.org/10.32628/IJSRST196613 Journal URL : http://ijsrst.com/IJSRST196613 